\title{
KAJIAN FONOLOGI BAHASA INDONESIA DALAM KUMPULAN VIDEO MAK BETI KARYA ARIF MUHAMMAD
}

\author{
Muh. Syamsul Ma'arif, Siti Qorifatul Robayanah \\ IAI Darussalam Blokagung Banyuwangi \\ Syamsulmaarif@iaida.ac.ad \\ sitiqorifatul@gmail.com
}

\begin{abstract}
Abstrak
Tujuan penelitian ini adalah mendeskripsikan unsur segmental dalam ujaran video Mak Beti dan perubahan bunyi/fonem akibat dari perkembangan sejarah dalam ujaran video Mak Beti. Jenis yang digunakan dalam dalam penelitian ini adalah analisis kualitatif deskriptif. Penelitian ini adalah penelitian pustaka dengan menggunakan sumber data berupa audio virtual dan visual sebuah vlogger karya Arif Muhammad.Teknik pengumpulan yang digunakan adalah menggunakan teknik simak dan teknik catat adapun langkahlangkah yang dilakukan dalam pengumpulan data sebagai berikut (1) pengamatan langsung pada video Mak Beti, (2) pemahaman ujaran dan mencatat data. Teknik analisis data data yang dilakukan adalah dengan teknik pengumpulan data, reduksi data, penyajian data dan penarikan kesimpulan. Hasil penelitian dan pembahasan dalam video Mak Beti karya Arif Muhammad unsur segmental dan perubahan bunyi/fonem akibat dari perkembangan sejarah. Unsur segmental dalam pembahasan ini meliputi vokal, konsonan dan semivokal. Sedangkan perubahan bunyi/fonem akibat dari perkembangan sejarah yang dibahas pada ujaran Mak Beti meliputi kontraksi mencakup aferesis, apokop sinkop. Diftongisasi, monoftongisasi dan anaftiksis mencakup epentesis, paragog.
\end{abstract}

Kata kunci: Kajian Fonologi, Video Mak Beti.

\begin{abstract}
The purpose of this study was to describe the segmental elements in Mak Beti's video utterances and changes in sound / phonemes resulting from historical developments in Mak Beti's video utterances. The type used in this research is descriptive qualitative analysis. This research is a library research using data sources in the form of virtual audio and visuals of a vlogger by Arif Muhammad. The collection techniques used are observing and note-taking techniques, while the steps taken in collecting data are as follows (1) direct observation on the video Mak Beti, (2) understanding speech and recording data. The data analysis technique used is the data collection technique, data reduction, data presentation and conclusion drawing. The results of research and discussion in the video Mak Beti by Arif Muhammad are segmental elements and changes in sound / phonemes as a result of historical developments. The segmental elements in this discussion include vowels, consonants and
\end{abstract}


semivowels. Meanwhile, changes in sound / phonemes as a result of historical developments discussed in Mak Beti's utterances include contraction including apheresis, syncope apocope. Diftongization, monophthongization and anaphthixis include epentesis, paragraph.

Keywords: Phonological Studies, Video of Mak Beti.

\section{A. Pendahuluan}

Bahasa pada hakikatnya adalah bunyi yang dipergunakan oleh manusia sebagai sarana komunikasi. Bahasa dipandang secara umum sebagai sarana komunikasi yang khas dan unik oleh penggunanya. Penggunaan suatu bahasa untuk berinteraksi antar warganya apabila diperhatikan dengan seksama bahasa yang digunakan warga satu dengan yang lain agak berbeda dengan bahasa yang dipergunakan oleh warga lainnya. Perbedaan bentuk penggunaan bahasa tersebut terdapat pada bunyi atau lafal, pilihan kata, bahkan pada struktur kalimatnya.

Tuturan bahasa terdiri atas bunyi dan tidak sembarang bunyi saja, bunyibunyi tertentu, yang agak berbeda- beda menurut bahasa tertentu (Verhaar, 2010: 10 dalam skripsi kajian fonologi dan leksikologi bahasa jawa di Desa Sambak Kecamatan Kajoran Kabupaten Magelang oleh Munawaroh 2012). Wujud dari penggunaan bahasa yang menunjukkan perbedaan kecil maupun besar, berupa perbedaan- perbedaan satuan bunyi fonem sampai pada pengungkapan kalimatnya, itulah yang disebut variasi bahasa. Bahkan tidak ada satu bahasa yang tidak mempunyai variasi bahasa.

Variasi bahasa memiliki perbedaan ucapan seseorang dari waktu ke waktu yang lain dan perbedaan suatu tempat ke tempat yang lain dengan memperhatikan lafal, intonasi atau perbedaan kata yang diucapkan oleh para penuturnya. Jadi, variasi bahasa sangatlah banyak jumlahnya. Banyaknya variasi bahasa ini tidak lain disebabkan karena setiap pemakai bahasa memiliki cara dan ragam berbahasa secara khusus, yaitu antara pemakai bahasa yang satu dengan yang lainnya memiliki perbedaan. Ragam perkembangan cara inilah yang disebut idiolek. Tiap orang merupakan pembentuk idiolek yang mempunyai ciri khas bahasa sendiri- sendiri. Jadi, idiolek adalah ciri-ciri keseluruhan cara seseorang menggunakan bahasa sejauh mulai berbicara sampai tua. 
Bahasa adalah salah satu bagian dalam kebudayaan yang ada pada semua masyarakat di dunia. Bahasa terdiri atas bahasa lisan dan tulisan. Sebagai bagian dari kebudayaan, bahasa juga turut ambil bagian dalam peran manusia karena memiliki fungsi sebagai alat komunikasi yang terus berkembang sesuai dengan perkembangan peradaban manusia itu sendiri. Karena bagian dari budaya dan peranannya terhadap manusia inilah, maka bahasa perlu dilestarikan, terutama yang berkenaan dengan pemakaian bahasa daerah, karena merupakan lambang identitas suatu daerah, masyarakat, keluarga dan lingkungan.

Menurut Chaer (2009: 5 dalam artikel fonologi bahasa Minangkabau di Kenagarian Padang Laweh Kabupaten Sijunjung oleh Ella Sumidita, Ermanto, Ngusman 2013) fonologi adalah bunyibahasa sebagai satuan terkecil dari ujaran beserta dengan "gabungan" antarbunyi yang membentuk silabel atau suku kata dan juga dengan unsur-unsur suprasegmental, seperti tekanan, nada, hentian dan durasi. Batasan yang telah dikemukakan Chaer tentang fonologi adalah bidang ilmu bahasa yang khusus mempelajari bunyi-bunyi bahasa yang signifikan, yaitu semua bunyi bahasa yang bersifat membedakan arti. Dengan begitu, berbeda halnya dengan fonetik yang mempelajari semua bunyi bahasa secara umum, maka fonologi mengamati bahasa tertentu saja, atau bunyi bahasa dari suatu bahasa tertentu, berdasarkan fungsinya bunyi bahasadapat membedakan arti atau makna leksikal dalam sistem bahasa tersebut.

Manfaat fonologi dalam penyusunan ejaan Bahasa. Ejaan adalah penggambaran bunyi ujar suatu Bahasa. Karena bunyi ujar ada dua unsur, yaitu segmental dan suprasegmental, maka ejaan pun menggambarkan atau melambangkan kedua unsur bunyi ujar tersebut. Perlambangan unsur segmental bunyi ujar tidak hanya bagaimana melambangkan bunyi-bunyi ujar dalam bentuk tulisan atau huruf, tetapi juga bagaimana menuliskan bunyibunyi ujar dalam bentuk kata, frase, klausa, dan kalimat, bagaimana memenggal suku kata, bagaimana menuliskan singkatan, nama orang, lambinglambang teknis keilmuan, dan sebagainya. Perlambangan unsur suprasegmental bunyi ujar 
menyangkut bagaimana melambangkan tekanan, nada, durasi, jeda, dan intonasi. (Masnur Muslich 2015)

Tata cara penulisan bunyi ujar (baik segmental maupun supraegmental) ini bisa memanfaatkan hasil kajian fonologi, terutama hasil kajian fonemik terhadap bahasa yang bersangkutan. Sebagai contoh, ejaan bahasa Indonesia yang selama ini telah diterapkan dalam penulisan memanfaatkan hasil studi fonologi bahasa Indonesia, terutama yang berkaitan dengan pelambangan fonem. Oleh karena itu, ejaan bahasa Indonesia dikenal dengan istilah ejaan fonemis. (Mansur Muslich 2015)

Fonetik dan fonemik keduanya termasuk bidang fonologi. Fonetik bertolok ukur pada analisis suatu masalah bunyi-bunyi bahasa tanpa menghiraukan fungsi masing-masing bunyi tersebut dalam ucapan. Fonemik berusaha menganalisis bunyi-bunyi yangmana ia berperan sebagai pembela makna. Bunyi-bunyi tersebut dalam ilmu bahasa disebut fonem. Berdasarkan dimana beradanya bunyi-bunyi bahasa itu ketika dikaji, dapat dibedakan adanya tiga macam fonetik, yaitu fonetik artikulatoris, fonetik akustik dan, fonetik auditoris.

Amril dan Ermanto (2007: 96 dalam artikel fonologi bahasa Minangkabau di Kenagarian Padang Laweh Kabupaten Sijunjung oleh Ella Sumidita, Ermanto, Ngusman 2013) mengemukan bahwa fonem vokal maupun fonem konsonan adalah suatu bentuk bunyi-bunyi segmental yang membentuk untaian kata, frasa, klausa, kalimat, dan wacana. Fonem vokal dan konsonan apabila dikaji dari prilaku kebahasaannya akan menghasilkan beberapa jenis seperti vokal, konsonan, semivokal, diftong, deret vokal, gugus konsonan, dan deret konsonan.

Perubahan bunyi/fonem akibat dari perkembangan sejarah tidak berkaitan dengan kajian fonologi, melainkan berkenaan dengan pemakaian sejumlah unsur leksikal di dalam masyarakat dan budayanya. Perubahan yang berkenaan dengan perkembangan sejarah pemakaian bahasa ini, antara lain, adalah proses kontraksi (penyingkatan), metatesis, diftongisasi, monoftongisasi, dan anaptiksis. 
Fonologi adalah bidang linguistik yang didalamnya mempelajari, menganalisis dan membicarakan tentang runtunan bunyi-bunyi bahasa (Chaer, 2009: 102). Dalam hal ini adalah fonologi bahasa Indonesia dalam kumpulan video Mak Beti karya Arif Muhammad.

Menurut medcom.id Jakarta, Arif Muhammad adalah seorang pria kelahiran 1992 asal Binjai, Sumatera Utara lulusan studi pariwisata. Konten Mak Beti yang dibuat sejak dia mengenal Instagram tahun 2013. Wawancara bersama Arief Muhammad (Pocong Juga Poconggg) yang dilaksanakan pada November tahun lalu, Arif Muhammad saat itu bekerja di Abu Dhabi sebagai house keeping hotel. Arif Muhammad telah menjadi bintang baru sejak Keluarga Mak Beti, serial drama keluarga besutannya banyak ditonton di YouTube. Per episode menyajikan realita yang terjadi di Binjai, kampung halaman Arif. YouTube Chanel Arif Muhammad memulai langkah ke dunia YouTube dengan polah menggelitik sebagai Mak Beti itu pada 18 Januari 2017 meski demikian, sosok Mak Beti lahir lebih awal tepatnya pada tahun 2013 karakter ini pertama kali dia munculkan melalui video instagram. Chanel ini termasuk dalam kategori yang memiliki pertumbuhan video cepat karena sudah lebih dari 116 video yang mengisi YouTube chanel Arif Muhammad dan telah ditonton sebanyak 985.193.954 pada Oktober 2019 lalu. Dan sudah memiliki 7,01 juta Subscribe chanel ini juga memiliki Views870 jutaan.

Dari pemaparan diatas alasan peneliti memilih objek dalam kajian fonologi bahasa Indonesia karena belum ada yang meneliti bahasa yang digunakan Arif Muhammad dalam kontennya Mak Beti, selain itu bahasa dalam konten tersebut hampir sama dengan bahasa Indonesia tetapi logatnya yang berbeda mungkin ada beberapa bahasa yang tidak sama dengan bahasa Indonesia. Dari situlah peneliti ingin meneliti tentang kajian fonologi bahasa Indonesia dalam kumpulan video mak beti karya Arif Muhammad.

\section{B. Landasan Teori}

1. Bahasa

Bahasa pada hakikatnya adalah bunyi yang dipergunakan oleh manusiasebagai sarana komunikasi. Bahasa dipandang secara umum sebagai 
sarana komunikasi yangkhas dan unik oleh penggunanya. Penggunaan suatu bahasa untuk berinteraksiantarwarganya apabila diperhatikan dengan seksama bahasa yang digunakan wargasatu dengan yang lain agak berbeda dengan bahasa yang dipergunakan oleh wargalainnya. Perbedaan bentuk penggunaan bahasa tersebut terdapat pada bunyi ataulafal, pilihan kata, bahkan pada struktur kalimatnya.

Tuturan bahasa terdiri atas bunyi dan tidak sembarang bunyi saja, bunyibunyi tertentu, yang agak berbeda- beda menurut bahasa tertentu (Verhaar, 2010: 10 dalam skripsi kajian fonologi dan leksikologi bahasa jawa di Desa Sambak Kecamatan Kajoran Kabupaten Magelang oleh Munawaroh 2012). Wujud dari penggunaan bahasa yang menunjukkan perbedaan kecil maupun besar, berupa perbedaan- perbedaan satuan bunyi fonem sampai pada pengungkapan kalimatnya, itulah yang disebut variasi bahasa. Bahkan tidak ada satu bahasa yang tidak mempunyai variasi bahasa.

2. Video

Video adalah suatu teknologi guna untuk menangkap, merekam, memproses,mentransmisikan serts menata ulang gambar bergerak. Yang mana biasanya menggunakan film seluloid, sinyal elektronik, atau media berupa digital. Digital video sendiri merupakan suatu jenis sistem video recording yang mana bekerjanya menggunakan sistem digital dibandingkan dengan analog dalam hal representasi videonya. Dan biasanyajuga digital video direkam dalam tape, lalu didistribusikan melalui optical disc, misalnya VCD dan DVD.

(Wikipedia)

\section{Fonologi}

Secara etimologi fonologi terbentuk dari kata fon yaitu bunyi dan logi yang artinya ilmu. Fonologi adalah bidang linguistik yang mempelajari, menganalisis dan membicarakan runtunan bunyi-bunyi bahasa.(Chaer, 2009: 102). Kemudian, Kridalaksana (2009) berpendapat dalam kamus linguistik, fonologi adalah ilmu tentang bidang dalam linguistik yang menyelidiki bunyi-bunyi bahasa menurut fungsinya. Dengan begitu dapat disimpulkan bahwa, garapan 
ilmu fonologi terbagi menjadi dua yaitu, fonetik dan fonemik. Fonetik merupakan ilmu fonologi yang memandangbahasa hanya sebagai bunyi utuh, sedangkan fonemik memandang bahasa sebagai suatuunsur yang membedakan makna.

\section{Unsur Segmental}

Klasifikasi bunyi segmental berdasarkan berbagai macam kriteria, yaitu (1) ada tidaknya gangguan, (2) mekanisme udara, (3) arah udara, (4) pita suara, (5) lubang lewatan udara, (6) mekanisme artikulasi, (7) cara gangguan, (8) maju mundur lidah, (9) tinggi rendahnya lidah, dan (10) bentuk bibir.

5. Vokal

Vokal merupakan bunyi bahasa yang dihasilkan dengan melibatkan pita suara tanpa penyempitan atau penutupan apapun pada tempat pengartikulasian manapun (Verhaar, 2010: 33). Vokal adalah suara yang dapat atau memiliki bunyi, atau suara yang keluar disebabkan keluarnya angin dari paru-paru kemudian dikeluarkan dari mulut tanpa hambatan.

Wendi Widya Ratna Dewi (2009: 15) dalam buku fonologi bahasa Indonesia berpendapat bahwa vokal merupkan bunyi bahasa yang dihasilkan tapa menghambat alat bicara. Jadi, bunyi vokal dihasilkan tanpa artikulasi.

Hambatan pada vokal hanya terdapat pada pita suara.

6. Perubahan bunyi/fonem

1. Akibat dari perkembangan sejarah

Perubahan bunyi akibat dari perkembangan sejarah ini tidak berkaitan dengan kajian fonologi, melainkan berkenaan dengan pemakaian sejumlah unsur leksikal di dalam masyarakat dan budayanya. Perubahan yang berkenaan dengan perkembangan sejarah pemakaian bahasa ini, antara lain, adalah proses kontraksi (penyingkatan), metatesis, diftongisasi, monoftongisasi, dan anaptiksis.

\section{Kerangka Pemikiran}

Kerangka berpikir dalam penelitian ini dimulai dengan kajian fonologi bahasa Indonesia dalam kumpulan video Mak Beti karya Arif Muhammad. Di Indonesia, penggunaan blog video mulai disadari ketika pada tahun 2009 muncul sebuah video rekaman pribadi seorang aktris dan penyanyi muda terkenal 
bernama Marshanda, yang tersebar luas di YouTube dan menjadi topik yang segera hangat dibicarakan saat itu, karena video tersebut berisikan ungkapan perasaan pribadi sang artis.

Selain itu, fenomena blog video yang terjadi pada tahun 2010 di Indonesia juga ditunjukkan dengan hadirnya dua orang gadis muda asal Jawa Barat bernama Sinta dan Jojo yang merekam diri mereka sedang menari dan menyanyikan lagu-lagu secara Lipsync, salah satunya yang paling membuat mereka tenar ialah lagu "Keong Racun”. Popularitas blog video Sinta dan Jojo yang menyanyikan lagu dengan lipsync ditunjukkan dengan pemberitaan di media massa, serta animo masyarakat yang meniru gaya menari mereka berdua, bahkan ada yang menjadikannya sebagai suatu kompetisi oleh masyarakat lokal di Indonesia.

Popularitas blog video di Indonesia, terutama yang hadir di situs YouTube juga disusul dengan blog video oleh Gamaliel dan Audrey, sepasang kakakberadik yang membagi rekaman-rekaman video mereka berdua sedang menyanyikan lagu-lagu milik penyanyi populer. Aktivitas yang dilakukan Gamaliel dan Audrey ini dikenal juga dengan istilah cover atau cover version, yaitu menyanyikan kembali lagu-lagu dari penyanyi yang sudah ada atau sudah populer, di mana aktivitas ini banyak dilakukan oleh para video blogger di YouTube. Video blogger juga bermanfaat mengasah kemampuan menulis untuk menjadi penulis terbaik adalah dengan menulis. Jika kita ingin melakukannya. kita dapat memulai dengan menulis artikel dalam topik tertentu secara rutin.

\section{Metode Penelitian}

Jenis penelitian yang dilakukan oleh penulis adalah penelitian kualitatif. Penelitian kualitatif adalah tradisi tertentu dalam ilmu pengetahuan social yang secara fundamental bergantung pada pengamatan manusia dalam kawasannya sendiri dan berhubungan dengan masyarakat tersebut melalui bahasanya, serta peristilahannya (Djajasudarma, 1993: 11). Dalam penelitian kualitatif prosedur yang menghasilkan data deskriptif berupa data simak dan catat pada pengamatan video. Dengan begitu, penulis tidak menggunakan angka dalam 
mengumpulkan data serta dalam pembahasan dan memberikran penafsiran terhadap hasilnya.

Adapun Sumber data dalam penelitian ini adalah berupa data catatan hasil simak video informan. Informan tersebut adalah kumpulan video Mak Beti karya Arif Muhammad merupakan data primer yang didapatkan dari alamat http://www.youtube.com/result?search_query=mak+beti salah satu judul yang diambil adalah Mak Beti Ngidam Apa.

Untuk mendapatkan data fonologi yang meliputi vokal, konsonan, semivokal, perubahan bunyi/fonem dalam kumpulan video Mak Beti karya Arif Muhammad. Dalam penelitian ini, maka dibuatlah kisi-kisi instrument serta korpus yang digunakan untuk mendapatkan data-data penelitian. Tabel

\section{1}

Kisi-Kisi Instrumen Data Fonologi Vokal, Konsonan, Semivokal, Perubahan Bunyi/Fonem Dalam Kumpulan Video Mak Beti Karya Arif Muhammad.

\begin{tabular}{|c|c|c|}
\hline No & $\begin{array}{l}\text { Nilai yang } \\
\text { Dianalisis }\end{array}$ & Indikator \\
\hline 1. & Vokal & $\begin{array}{l}\text { a. Vokal berdasarkan tinggi rendahnya posisi lidah. } \\
\text { b. Vokal berdasarkan bagian lidah yang bergerak. } \\
\text { c. Vokal berdasarkan posisi strukturnya. } \\
\text { d. Vokal berdasarkan bentuk bibir saat vokal diucapkan. }\end{array}$ \\
\hline 2. & Konsonan & $\begin{array}{l}\text { a. Konsonan hambat letup (stop, plosives). } \\
\text { b. Konsonan nasal (sengau). } \\
\text { c. Konsonan paduan (affricates). } \\
\text { d. Konsonan sampingan (laterals). } \\
\text { e. Konsonan geseran atau fikatif. } \\
\text { f. Konsonan getar (trills, vibrants). }\end{array}$ \\
\hline 3. & Semivokal & $\begin{array}{l}\text { a. Semivokal bilabial. } \\
\text { b. Semivokal medio-palatal. }\end{array}$ \\
\hline
\end{tabular}




\begin{tabular}{|l|l|ll|}
\hline 4. & $\begin{array}{l}\text { Perubahan } \\
\text { bunyi/fone }\end{array}$ & a. & Kontraksi (penyingkatan) \\
$\mathrm{m}$ & b. & Diftongisasi \\
& & c. & Monoftongisasi \\
d. & Anaftiksis \\
\hline
\end{tabular}

Tabel 1.2

Korpus Data Penelitian

\begin{tabular}{|c|c|c|c|}
\hline No & $\begin{array}{c}\text { Nilai } \\
\text { yang } \\
\text { Dianali } \\
\text { sis }\end{array}$ & $\begin{array}{l}\text { Indi } \\
\text { Kator }\end{array}$ & Deskripsi Data \\
\hline 1. & Vokal & $\begin{array}{l}\text { a. Vokal berdasarkan } \\
\text { tinggi rendahnya } \\
\text { posisi lidah. } \\
\text { b. Vokal berdasarkan } \\
\text { bagian lidah yang } \\
\text { bergerak. } \\
\text { c. Vokal berdasarkan } \\
\text { posisi strukturnya. } \\
\text { d. Vokal berdasarkan } \\
\text { bentuk bibir saat } \\
\text { vokal diucapkan. }\end{array}$ & $\begin{array}{l}\text { "apa nggak di tengok matahari udah } \\
\text { limbung kearah barat". } \\
\text { " kerja nggak nyusahin aja, makan } \\
\text { tidUr terUs". } \\
\text { "jam səgini belum pulang-pulang". } \\
\text { "mangkanya aku nggak mau } \\
\text { poligami". }\end{array}$ \\
\hline
\end{tabular}




\begin{tabular}{|c|c|c|c|}
\hline 2. & $\begin{array}{l}\text { Konson } \\
\text { an }\end{array}$ & $\begin{array}{l}\text { a. Konsonan hambat } \\
\text { letup (stop, plosives). } \\
\text { b. Konsonan nasal } \\
\text { (sengau). } \\
\text { c. Konsonan paduan } \\
\text { (affricates). } \\
\text { d. Konsonan sampingan } \\
\text { (laterals). } \\
\text { e. Konsonan geseran } \\
\text { atau fikatif. } \\
\text { f. Konsonan getar } \\
\text { (trills, vibrants). }\end{array}$ & $\begin{array}{l}\text { "gas bumi ini muncul". } \\
\text { "pulang kao naik apa? Naik lembu". } \\
\text { "nanti ku jelaskan bahayanya virus ini } \\
\text { Martha". } \\
\text { "itukan dulu sekarang beda namanya } \\
\text { Beti udah besar mak". }\end{array}$ \\
\hline 3. & $\begin{array}{l}\text { Semivo } \\
\text { kal }\end{array}$ & $\begin{array}{l}\text { a. Semivokal bilabial. } \\
\text { b. Semivokal } \\
\text { mediopalatal. }\end{array}$ & $\begin{array}{l}\text { "kao belikan telor ini ya, ini } \\
\text { duwetnya". } \\
\text { "iiih Cuma beli telor dua bijipun ke } \\
\text { grosir sana, yakin males kali aku". }\end{array}$ \\
\hline 4. & $\begin{array}{l}\text { Peruba } \\
\text { han } \\
\text { bunyi/f } \\
\text { onem }\end{array}$ & $\begin{array}{l}\text { a. Kontraksi } \\
\text { (penyingkatan) } \\
\text { b. Diftongisasi } \\
\text { c. Monoftongisasi } \\
\text { d. Anaftiksis }\end{array}$ & $\begin{array}{l}\text { "ini apel ijo aku cuci dululah". } \\
\text { "mangkanya aku nggak mau } \\
\text { poligami". kok jam segini belom } \\
\text { pulang-pulang". kalo orangkaya kayak } \\
\text { ginilah pakek hangmer". }\end{array}$ \\
\hline
\end{tabular}

Validasi terhadap peneliti sebagai instrumen meliputi validasi terhadap pemahaman metode penelitian kualitatif, penguasaan wawasan terhadap bidang yang diteliti, kesiapan peneliti untuk memasuki obyek penelitian, baik secara akademik maupun logistiknya. Yang melakukan validasi adalah peneliti itu sendiri melalui evaluasi diri seberapa jauh pemahaman terhadap metode kualitatif, penguasaan teori dan wawasan terhadap bidang yang diteliti, serta kesiapan dan bekal memasuki lapangan. 
Penelitian kualitatif sebagai human instrumen, berfungsi menetapkan focus penelitian, memilih informan sebagai sumber data, melakukan pengumpulan data, menilai kualitas data, analisis data, menafsirkan data dan membuat kesimpulan atas temuannya. Sugiyono (2016: 222)

\section{Hasil dan Pembahasan}

Setelah mengutip berbagai video yang terdapat dalam kumpulan video Mak Beti karya Arif Muhammad. Maka ditemukan berbagai pembahasan yang peneliti lakukan sebagai berikut:

1. Vokal

Berkenaan dengan penentuan bunyi vokal berdasarkan posisi lidah ada konsep yang disebut vokal kardinal (Jones 158:18, dalam buku fonologi bahasa Indonesia Abdul Chaer 2013), yang berguna untuk membandingkan vokal-vokal suatu bahasa di antara bahasa-bahasa lain. Konsep vokal kardinal ini menjelaskan adanya posisi lidah tertinggi, terendah, dan terdepan dalam memproduksi bunyi vokal itu. Diketahui dari tabel diatas cara mengucapkan vokal /a/ yaitu dengan merendahkan lidah depan (ujung lidah) serendah mungkin, vokal /i/ diucapkan dengan meninggikan lidah depan setinggi mungkin tanpa menyebabkan terjadinya konsonan geseran, dan vokal /u/ diucapkan dengan menaikkan pangkal lidah setinggi mungkin. Berikut merupakan konsepkonsep yang terkandung dalam vokal kardinal:

1) Tinggi rendahnya posisi lidah

Berdasarkan tinggi rendahnya posisi lidah, bunyi-bunyi vokal dapat dibedakan atas:

a. Vokal tinggi atas, terdapat pada bunyi [i] dan $[\mathrm{u}]$

b. Vokal tinggi bawah, terdapat pada bunyi [I] dan [U]

c. Vokal sedang atas, terdapat pada bunyi [e] dan [o]

d. Vokal sedang bawah, terdapat pada bunyi [E] dan [0]

e. Vokal sedang tengah, terdapat pada bunyi [ə] 
f. Vokal rendah, terdapat pada bunyi [a]

2) Maju mundurnya lidah

Berdasarkan maju mundurnya lidah, bunyi vokal dapat dibedakan atas:

a. Vokal depan, terdapat pada bunyi [i], [e], dan [a]

b. Vokal tengah, terdapat pada bunyi [ə]

c. Vokal belakang, terdapat pada bunyi [u] dan [o]

3) Struktur

Struktur pada bunyi vokal adalah jarak antara lidah dengan langitlangit keras (palatum). Maka, berdasarkan strikturnya bunyi vokal dapat dibedakan menjadi:

a. Bunyi /i/, /u/ masuk pada vokal tertutup, karena lidah diangkat setinggi mungkin mendekati langit-langit.

b. Bunyi /e/, /o/, /o/ masuk pada vokal semi tertutup, karena lidah diangkat dalam ketinggian sepertiga dibawah vokal tertutup.

c. Bunyi /E/, / / / masuk pada vokal semi terbuka, karena lidah diangkat dalam ketinggian sepertiga di atas vokal yang paling rendah.

d. Bunyi /a/ masuk pada vokal terbuka, karena lidah berada dalam posisi serendah mungkin.

4) Bentuk mulut

a. Vokal bundar, yaitu vokal yang diucapkan dengan bentuk mulut membundar. Dalam hal ini ada yang bundar terbuka seperti bunyi / / /, dan yang bundar tertutup seperti bunyi /o/ dan $/ \mathrm{u} /$.

b. Vokal tak bundar, yaitu vokal yang diucapkan dengan bentuk mulut tidak membundar, melainkan terbentang melebar, seperti bunyi /i/, bunyi /e/, dan bunyi /E/.

c. Vokal netral, yaitu vokal yang diucapkan dengan bentuk mulut tidak bundar dan tidak melebar, seperti bunyi /a/.

Berdasarkan keempat kriteria yang dibicarakan tersebut, maka nama-nama vokal dapat disebutkan sebagai berikut:

[i] adalah vokal depan, tinggi (atas), tak bundar, tertutup. 
[I] adalah vokal depan, tinggi (bawah), tak bundar, tertutup.

[u] adalah vokal belakang, tinggi (atas), bundar, tertutup.

[U] adalah vokal belakang, tinggi (bawah), bundar, tertutup.

[e] adalah vokal depan, sedang (atas), tak bundar, semi tertutup.

[E] adalah vokal depan, sedang (bawah), tak bundar, semi terbuka.

[ə] adalah vokal tengah, sedang, tak bundar, semi tertutup.

[o] adalah vokal belakang, sedang (atas), bundar, semi tertutup.

[॰] adalah vokal belakang, sedang (bawah), bundar, semi terbuka.

[a] adalah vokal belakang, rendah, netral, terbuka.

2. Konsonan

Konsonan adalah bunyi bahasa yang diproduksi dengan cara, setelah arus ujar keluar dari glotis, lalu mendapatkan hambatan pada alat-alat ucap tertentu dalam rongga mulut atau rongga hidung (Abdul Chaer fonologi bahasa Indonesia 2013:48).

Wendi Widya Ratna Dewi (2009: 15) dalam buku fonologi bahasa Indonesia berpendapat bahwa konsonan merupakan bunyi bahasa yang dihasilkan dengan menghambat udara pada alat bicara. Jadi, bunyi konsonan dihasilkan dengan artikulasi.

1) Konsonan hambat letup

a. Konsonan hambat letup bilabial. Konsonan ini terjadi bila artikulator aktifnya bibir bawah dan artikulator pasifnya bibir atas. Bunyi yang dihasilkan adalah [p] dan [b].

b. Konsonan hambat letup medio-palatal/laminopalatal. Konsonan ini terjadi bila artikulator aktif tengah lidah dan artikulator pasifnya langitlangit keras. Bunyi yang dihasilkan adalah [c] dan [j].

c. Konsonan hambat letup dorso-velar. Konsonan ini terjadi bila akulator aktifnya pangkal lidah dan artikulator pasifnya langit-langit lunak (langit-langit bawah). Bunyi yang dihasilkan adalah [k] dan [g]. 
d. Konsonan hamzah/glotal. Konsonan ini terjadi dengan menekan rapat yang satu terhadap yang lain pada seluruh pita suara. Langit-langit lunak beserta anak tekak ditekan ke atas sehingga arus udara terhambat beberapa saat. Bunyi yang dihasilkan adalah [?].

2) Konsonan nasal /sengau

Wendi Widya Ratna Dewi (2009: 15) konsonan nasal (sengau) adalah konsonan yang dibentuk dengan menghambat rapat (menutup) jalan udara dari paru-paru melalui rongga hidung. Bersama dengan itu langit-langit lunak beserta nanak tekaknya diturunkan sehingga udara keluar melalui rongga hidung. Berdasarkan tempat artikulasinya, konsonan nasal dibedakan sebagai berikut.

a. Konsonan nasal bilabial. Konsonan ini terjadi bila alkulator aktifnya bibir bawah dan artikulator pasif bibir atas. Nasal yang dihasilkan [m].

b. Konsonannasal mediopalatal/laminopalatal. Konsonan ini terjadi bila alkulator aktifnta tengah lidah dan alkulator pasifnya langit-langit keras. Bunyi yang dihasilkan $[\eta]$ dalam tulisan ny.

c. Konsonan nasal apiko-alveolar. Konsonan ini terjadi bila artikulator aktifnya ujung lidah dan artikulator pasifnya gusi. Bunyi yang dihasilkan adalah $[\mathrm{n}]$.

d. Konsonan nasal dorso-velar. Konsonan ini terjadi bila alkulator aktifnya pangkal lidah dan alkulator pasifnya langit-langit lunak. Bunyi yang dihasilkan adalah [y]. 3) Konsonan paduan (affricates)

Konsonan paduan adalah konsonan hambat jenis khusus. Tempat artikulasinya ujung lidah dan gusi belakang [ts] dan [d]. Dalam bahasa Indonesia jarang atau tidak menggunakan [ts] dan [d].

4) Konsonan sampingan (laterals)

Konsonan sampingan dibentuk dengan menutup arus udara di tengah rongga mulut sehingga udara keluar melalui kedua samping atau sebuah samping saja. Tempat artikulasinya ujung lidah dengan gusi. Bunyi yang dihasilkan [1].

5)Konsonan geseran atau fikatif 
Konsonan geseran atau frikatif adalah konsonan yang dibentuk dengan menyempitkan jalannya arus udara yang diembuskan dari paru-paru sehingga jalannya udara terhalang dan keluar dengan bergeser. Menurut artikulasinya, konsonan geseran dibedakan sebagai berikut.

a. Konsonan geseran labio-dental. Konsonan ini terjadi bila altikulator aktifnya bibir bawah dan artikulator pasifnya gigi atas. Bunyi yang dihasilkan [f] dan [v].

b. Konsonan geseran lamino-alveolar. Konsonan ini terjadi bila altikulator aktifnya daun lidah (lidah bagian samping) dan ujung lidah, sedangkan artikulator pasifnya gusi. Bunyi yang dihasilkan [s] dan [z].

c. Konsonan geseran dorso-velar. Konsonan ini terjadi nila altikulator aktifnya pangkal lidah dan artikulator pasifnya langit-langit lunak. Bunyi yang dihasilkan [x].

d. Konsonan geseran laringal. Konsonan ini terjadi bila altikulatornya sepasang pita suara dan glotis dalam keadaan terbuka. Bunyi yang dihasilkan $[\mathrm{h}]$.

6) Konsonan getar (trills, vibrants)

Konsonan getar adalah konsonan yang dibentuk dengan menghambat jalannya arus udara yang diembuskan dari paru-paru secara berulang-ulang dan cepat. Menurut tempat artiklasinya, konsonan getar dinamai konsonan getar apiko-alveolar. Konsonan ini terjadi bila altikulator aktif yang menyebabkan proses menggetar adalah ujung lidah dan altikulator pasifnya gusi. Bunyi yang dihasilkan [r].

3. Semivokal

1) Semivokal bilabial

Semivokal ini terjadi bila altikulator aktifnya bibir bawah dan artikulator pasif bibir atas. Bunyi yang dihasilkan [w].

2) Semivokal medio-palatal 
Semivokal ini terjadi bila artikulator aktifnya tengah lidah dan artikulator pasifnya langitlangit keras. Bunyi yang dihasilkan [y].

4. Perubahan Fonem/Bunyi

1) Beladangnya

Kata tersebut masuk pada perubahan bunyi anaftiksis paragog dikarenakan pada kata tersebut ada proses penambahan bunyi pada posisi akhir kata. Terdapat pada kalimat:

“ngajak mamak beladangnya nenekmu itu”.

2) Ujan

3) Udik

Kata tersebut masuk pada perubahan bunyi kontraksi aferesis dikarenakan pada kata tersebut ada proses penghilangan satu fonem atau lebih pada awal kata. Terdapat pada kalimat:

"jadi, sudah pada mudik orang-orang itu? Oalah udik-udik”.

"Siang, sore, ujan, petirpun beladang mamak sama nondongmu”.

4) Mager

Kata tersebut masuk pada perubahan bunyi kontraksi apokop dikarenakan pada kata tersebut ada proses penghilangan satu fonem atau lebih pada akhir kata. Terdapat pada kalimat:

“iis mager kali beti mak".

5) Ajala

Kata tersebut masuk pada perubahan bunyi kontraksi aferesis dikarenakan pada kata tersebut ada proses penghilangan satu fonem atau lebih pada awal kata. Terdapat pada kalimat:

“susah kali disuruh salat ajala”.

6) Jeret

Kata tersebut masuk pada perubahan bunyi monoftongisasi karena proses ini banyak terjadi dalam bahasa Indonesia akibat dari ingin memudahkan ucapan terdapat pada kalimat:

“nunggu mamakjeret sana-sini baru kao mau gerak”.

7) $\mathrm{Kao}$ 
Kata tersebut masuk pada perubahan bunyi monoftongisasi karena proses ini banyak terjadi dalam bahasa Indonesia akibat dari ingin memudahkan ucapan terdapat pada kalimat:

"nunggu mamak jeret sana-sini baru kao mau gerak".

\section{E. Simpulan}

Berdasarkan penelitian tentang kajian fonologi bahasa Indonesia dalam kumpulan video Mak Beti yang diambil dari chanel Arif Muhammad terbit april-juni 2020 dapat disimpulkan sebagai berikut:

1. Kajian fonologi unsur segmental

Bahasa yang digunakan dalam video Mak Beti yang dibahas peneliti tentang unsur segmental yaitu vokal, konsonan, dan semivokal. Huruf vokal yang meliputi /a/, /i/, /I/, /u/, /U/, /e/, /E/, /o/, /o/, /o/, huruf konsonan /b/, /c/, /d/, /f/, /g/, /h/, /j/, /k/, /?/, /l/, /m/, /n/, /p/, /r/, /s/, /t/, /v/, /x/, /z/ dan huruf semivokal meliputi /w/, dan /y/.

2. perubahan bunyi/fonem akibat dari perkembangan sejarah.

Dalam hal ini perubahan bunyi/fonem akibat dari perkembangan sejarah terdapat kontraksi yang didalamnya mencakup aferesis yaitu proses penghilagan satu fonem atau lebih pada awal kata dalam video Mak Beti terdapat kata "aus" dalam bahasa Indonesia pengucapan yang benar "haus". Apokop yaitu proses penghilangan satu fonem atau lebih pada akhir kata terdapat dalam video Mak Beti kata "mager" dalam bahasa Indonesia pengucapan yang benar "malas gerak" dengan penghilangan kata akhir "las" dan "rak" maka terjadilah penyingkatan "mager", kemudian mencakup sinkop yang merupakan proses peghilangan sebuah fonem atau lebih pada tengah kata dalam video Mak Beti telah ditemukan kata "tepat" yang mana dalam bahasa Indonesia pengucapan yang benar "tempat".

Diftongisasi yang merupakan proses perubahan vokal tunggal menjadi vokal rangkap secara berurutan hal ini ditemukan dalam video Mak Beti pada kata "mangkanya" dalam bahasa Indonesia pengucapan yang benar "makanya". 
Monoftongisasi yang merupakan proses perubahan dua buah vokal atau gugus vokal menjadi sebuah vokal hal ini ditemukan dalam video Mak Beti pada kata "sawet" dalam bahasa Indonesia pengucapan yang benar "sawit".

Anaftiksis yaitu proses penambahan bunyi yang mencakup anaftiksis protesis penambahan bunyi awal kata "wenak" dengan kata “enak", epentesis penambahan bunyi tengah kata dalam ditemukan kata "hangmer", dan paragog proses penambahan akrir kata ditemukan dalam bahasa Mak Beti “bikinin”.

Penelitian ini menitikberatkan pada fonologi unsur segmental dan perubahan fonem akibat dari perkembangan sejarah. Bagi peneliti selanjutnya, diharapkan dapat meneliti fonologi dengan unsur lainnya, guna untuk meningkatkan pemahaman kita dalam mempelajari ilmu bahasa Indonesia tentang tindak tutur yang diujarkan setiap manusia. Yang terjadi banyak variasi bahasa dalam setiap ujaran manusia maka peneliti harus teliti dalam mendiskripsikan data sehingga mendapatkan hasil yang baik dan benar.

\section{Daftar Pustaka}

Amril dan Ermanto. 2007. Fonologi bahasa Indonesia. Padang: UNP Press.

Chaer Abdul, 2013. Fonologi Bahasa Indonesia. Jakarta: Rineka Cipta.

Chaer Abdul, 2014. Linguistik Umum. Jakarta: Rineka Cipta

Chaer Abdul. 2009. Fonologi Bahasa Indonesia. Jakarta: Rineka Cipta.

Choiril Ikhwan, 2017. Perbedan Sistem Fonologi Bahasa Musi Dialek NgunangKecamatan Sanga Desa Kabupaten Musi BanyuasinDengan Bahasa Indonesia. Universitas Muhammadiyah Palembang.

Ella Sumidita1, Ermanto2, Ngusman3, 2013. Fonologi Bahasa Minangkabau

DiKenagarian Padang Laweh KabupatenSijunjun. Universitas Negeri Padang. https://www.youtube.com/results?search_query=mak+beti Mahsun, 2014. Metode Penelitian Bahasa. jakarta: Rajawali Pers.

Moleong, Lexy. 2005. Metodologi Penelitian Kualitatif. Bandung: PT Remaja Rosdakarya. 
Munawaroh, 2012.Kajian Fonologi Dan Leksikologi BahasaJawa Di Desa Sambak Kecamatan KajoranKabupaten Magelang. Universitas Muhammadiyah Purworejo.

Muslich Masnur, 2015. Fonologi Bahasa Indonesia Tinjauan Deskriptif Sistem Bunyi Bahasa Indnesia. Jakarta: PT Bumi Aksara.

Sugiyono, 2016. Metode Penelitian Kuantitatif dan Kualitatif, dan R\&D. Bandung: Alfabeta.

Wendi Widya Ratna Dewi, 2009. Fonologi Bahasa Indonesia. Klaten : PT Intan Pariwara. 